\title{
Corrosion inhibition by an aqueous extract of Ervatamia divaricata
}

\author{
P. Shanthy, ${ }^{1}$ J.A. Thangakani, ${ }^{2}$ S. Karthika, ${ }^{3}$ S.C. Joycee, ${ }^{4}$ \\ S. Rajendran ${ }^{4}\left(\mathbb{D} *\right.$ and J. Jeyasundari ${ }^{5}$ \\ ${ }^{1}$ Department of Chemistry, Sri Meenakshi Government Arts College for Women(A), \\ Maduari, India \\ ${ }^{2}$ Department of Chemistry, The American College, Madurai, India \\ ${ }^{3}$ Department of chemistry, Kundavai Nacchiyaar Government Arts College for Women(A), \\ Thanjavur, India \\ ${ }^{4}$ Corrosion Research Centre, Department of Chemistry, St Antony's College of Arts and \\ Science for Women, Dindigul 62405 India \\ ${ }^{5} P G$ Department of Chemistry, SVN College, Madurai, India \\ *E-mail: susairajendran@gmail.com
}

\begin{abstract}
The corrosion inhibition efficiency (IE) of Ervatamia divaricata extract (EDE) and $\mathrm{Zn}^{2+}$ system in controlling corrosion of carbon steel in ground water has been evaluated by weight loss method. Weight loss study reveals that the formulation consisting of $2.5 \mathrm{ml}$ of $E D E$ and $25 \mathrm{ppm}$ $\mathrm{Zn}^{2+}$ has $98 \%$ inhibition efficiency in controlling corrosion of carbon steel immersed in ground water. Synergism parameters, calculated on the basis of blocking effect, suggest that a synergistic effect exists between $E D E$ and $\mathrm{Zn}^{2+}$. FTIR study reveals that a protective film (blocking film) is formed on the metal surface consisting of $\mathrm{Fe}^{2+}-$ Corynanthean complex and $\mathrm{Zn}(\mathrm{OH})_{2}$. The anodic reaction is controlled by the $\mathrm{Fe}^{2+}-$ Corynanthean complex formed on the anodic sites of the metal surface and the cathodic reaction is controlled by $\mathrm{Zn}(\mathrm{OH})_{2}$ formed on the cathodic sites of the metal surface. The hardness of the metal surface containing the protective film is in between that of polished metal and that of the corroded metal in ground water. That is, the hardness of protective film is lower than that of polished metal but higher than that of corroded surface. This reveals that the protective film is very compact and close packed, due to blocking effect. Electrochemical studies such as polarisation study and AC impedance spectra have been employed to investigate the mechanistic aspects of the corrosion inhibition. In the presence of inhibitors, linear polarization resistance (LPR) increases, corrosion current decreases $\left(I_{\text {corr }}\right)$, charge transfer resistance $\left(R_{\mathrm{t}}\right)$ increases, double layer capacitance $\left(C_{\mathrm{dl}}\right)$ decreases, impedance increases and phase angle increases. Adsorption isotherm study reveals that the adsorption of inhibitors on the metal surface obeys the Langmuir adsorption isotherm.
\end{abstract}

Keywords: corrosion inhibition, carbon steel, green inhibitor, environmentally friendly inhibitior, Ervatamia divaricata, electrochemical studies, hardness of metal surface.

Received: December 11, 2020. Published: March 11, 2021

doi: $\underline{10.17675 / 2305-6894-2021-10-1-19}$ 


\section{Introduction}

Several inorganic inhibitors such as zinc, chromate, polyphosphate and nitrite were used as corrosion inhibitors. Also molybdate, phosphates, phosphonocarboxylic acids and polymers were used as inhibitors along with metal ions such as $\mathrm{Zn}^{2+}$. Though many synthetic compounds showed good anticorrosive activity, most of them are highly toxic to both human beings and environment. These toxic effects and ecological problem associated with the discharge of such materials have resulted in the development of other efficient and environmentally acceptable inhibitors. Hence the recent trend is the search for environmental friendly inhibitors. Most of the natural products are non-toxic, bio degradable and readily available in plenty. Various parts of plants - seeds, fruits, leaves, flowers etc. have been used as corrosion inhibitors. Several studies have been published [1-10] on the use of natural products as corrosion inhibitors. Anticorrosive property of dry Arecanut seed extract at electrode (aluminum) - electrolyte (hydrochloric acid) interface was studied by Raghavendra and Bhat [1]. Weight loss method and electrochemical studies were employed. Njoku et al. used natural products for materials protection. Corrosion protection of aluminium in hydrochloric acid by Kola nitida extract was investigated [2]. The adsorption of inhibitor molecules on the metal surface obey Langmuir adsorption isotherm. The utility of Eulychnia acida phil. (cactaceae) extracts as corrosion inhibitors for carbon steel in acidic media was studied by Venegas et al. [3]. Blocking active sites on the metal are reported as responsible for corrosion inhibition. Salhi et al. used natural product extract as eco-friendly corrosion inhibitor for mild steel in $1.0 \mathrm{M} \mathrm{HCl}$ [4]. Weight loss measurement and electrochemical studies were used. Al-Khaldi employed natural products as corrosion inhibitors for steel in $0.5 \mathrm{M}$ hydrochloric acid solution [5]. Lemon leaves extracts with saffron, almonds, guava leaves and Origanum majorana extracts were used as corrosion inhibitors. The effectiveness of copaiba oil loaded into a microemulsion system as a green corrosion inhibitor was reported by Emerenciano et al. [6]. Electrochemical methods were employed. Yahia et al. investigated the inhibitive effect of Zygophyllum Album extract on the sulfuric acid corrosion of mild steel grade Api API 5L X52 [7]. The inhibitor functions as mixed type of inhibitor. Abdel Rahman et al. have made a study of electropolishing inhibition of steel using natural products as a green inhibitor in ortho-phosphoric acid [8]. Thermodynamic parameters were derived. The inhibitory effect of Piper nigrum L. extract on the corrosion of mild steel in acidic media was investigated by De'Assis et al. [9]. Weight loss method was employed. Excellent corrosion inhibition efficiency was obtained. Aniba canelilla was used as a corrosion inhibitor of carbon steel by De'Barros et al. [10]. As the concentration of inhibitor increases, inhibition efficiency also increases. It is well known that Ervatamia divaricata flowers are useful in ayurvedic medicine. They are also used to depress the bone marrow resulting in temporary leucopenia. E. divaricata could have benefits as an anti-tumor drug [11]. The anti-oxidative effects of E. divaricata were studied by various investigators [11,12]. The major ingredients of E. divaricata are Vincosan, Corynanthean, Vallesiachotaman, Strychnan, Aspidospermatan, 
Plumeran, Eburan, Ibogan, Tacaman, Bis-indole. All of them have the structure of indole in common [13].

\section{Experimental}

\section{Preparation of Ervatamia divaricata extract}

An aqueous extract of Ervatamia divaricata leaves was prepared by grinding $50 \mathrm{~g}$ of shade dried Ervatamia divaricata leaves with distilled water, filtering the suspending impurities, and making up to $100 \mathrm{ml}$. The extract was used as corrosion inhibitor in the present study.

\section{Preparation of the specimens}

Carbon steel specimens $(0.026 \% \mathrm{~S}, 0.065 \% \mathrm{P}, 0.4 \% \mathrm{Mn}, 0.1 \% \mathrm{C}$ and rest iron) of the dimensions $1.0 \times 4.0 \times 0.2 \mathrm{~cm}$ were polished to a mirror finish, degreased with trichloroethylene, and used for the weight loss method and surface examination studies.

\section{Collection of ground water}

Ground water used for this study was collected from Kundavai Naachiyaar Govt. Arts College, Thanjavur, Tamil Nadu, India (Table 1).

Table 1. Physicochemical parameters of ground water.

\begin{tabular}{cc}
\hline Parameter & Ground water \\
\hline $\mathrm{pH}$ & 6.80 \\
Conductivity & $503 \mathrm{Mic} \mathrm{S} / \mathrm{cm}$ \\
Total dissolved solids & $352 \mathrm{ppm}$ \\
Chloride & $116 \mathrm{ppm}$ \\
Sulphate & $15 \mathrm{ppm}$ \\
Total hardness & $130 \mathrm{ppm}$ \\
\hline
\end{tabular}

\section{Weight loss method}

Carbon steel specimens were immersed in $100 \mathrm{ml}$ of a ground water containing various concentrations of the inhibitor in the presence of and absence of $\mathrm{Zn}^{2+}$ for a period of 3 days. The weights of the specimens before and after immersion were determined using a balance, Schimadzu AY62 model. The inhibition efficiency (IE) was then calculated using the relation

$$
I E=100 \cdot\left[1-\frac{W_{2}}{W_{1}}\right] \cdot \%
$$

Where:

$W_{1}$ : Corrosion rate (mdd) in the absence of inhibitor,

$W_{2}$ : Corrosion rate (mdd) in the presence of inhibitor. 


\section{Surface Examination Study}

The carbon steel specimens were immersed in various test solution for a period of 3 days. After three days, the specimens were taken out and dried. The nature of the film formed on the surface of the metal, specimens was analyzed by FTIR spectroscopy ( $\mathrm{KBr}$ method). The FTIR spectrum of the protective film was recorded by carefully removing the film mixed it with $\mathrm{KBr}$ and making the pellet. Infrared spectra were monitored in Perkin-Elmer make, model Spectrum two. Vicker hardness was recorded in Shimadzu make model HMV-27.

\section{Synergism Parameters}

Synergism parameters are indications of the synergistic effect existing between two inhibitors. While calculating the surface coverage importance is given to blocking effect. Synergism parameters were calculated using the relation

$$
S_{\mathrm{I}}=\left(1-\theta_{1+2}\right) /\left(1-\theta_{1+2}^{\prime}\right)
$$

Where

$\theta_{1+2}=\left(\theta_{1}+\theta_{2}\right)-\left(\theta_{1} \cdot \theta_{2}\right)$, being $\theta_{1}=$ surface coverage of substance 1 and $\theta_{2}=$ surface coverage of substance 2. $\theta_{1+2}^{\prime}=$ combined surface coverage of substances $1 \& 2 . \theta=$ surface coverage, which is given by IE\%/100. Synergism parameters are derived from inhibition efficiencies of the $E D E-\mathrm{Zn}^{2+}$ system.

\section{Electrochemical studies}

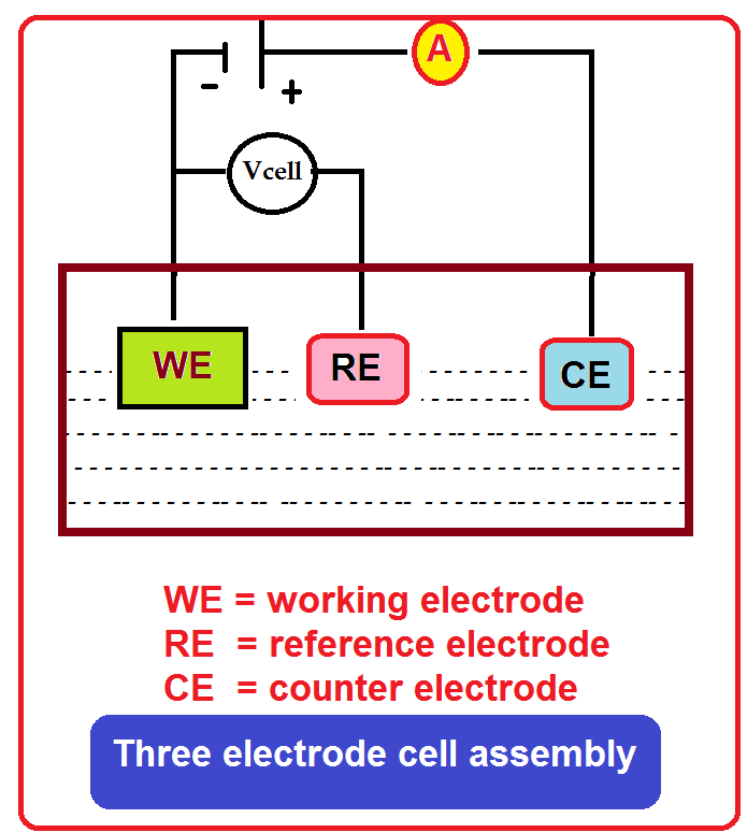

Scheme 1. Three electrode cell assembly. 
Corrosion resistances of carbon steel immersed in various test solutions were measured by Polarization study and AC impedance spectra. The experimental set is shown in Scheme 1.

\section{Polarization study}

Polarization studies were carried out in a CHI Electrochemical work station/analyzer, model $660 \mathrm{~A}$. It was provided with automatic $i_{\mathrm{R}}$ compensation facility. A three electrode cell assembly was used (Scheme 1). The working electrode was carbon steel. A SCE was the reference electrode. Platinum was the counter electrode. A time interval of 5 to 10 min was given for the system to attain a steady state open circuit potential. From polarization study, corrosion parameters such as corrosion potential $\left(E_{\text {corr }}\right)$, corrosion current $\left(I_{\text {corr }}\right)$, Tafel slopes anodic $b_{\mathrm{a}}$ and cathodic $b_{\mathrm{c}}$ and LPR (linear polarization resistance) value were measured. The scan rate $(\mathrm{V} / \mathrm{s})$ was 0.01 . Hold time at $\left(E_{\mathrm{fcs}}\right)$ was zero and quiet time was two seconds.

\section{AC Impedance spectra}

The same instrument and set-up used for polarization study was used to record AC impedance spectra also. A time interval of 5 to 10 min was given for the system to attain a steady state open circuit potential. The real part $\left(Z^{\prime}\right)$ and imaginary part $\left(-Z^{\prime \prime}\right)$ of the cell impedance were measured in ohms at various frequencies. AC impedance spectra were recorded with initial $E(\mathrm{~V})=0$, high frequency $\left(1 \cdot 10^{5} \mathrm{~Hz}\right)$, low frequency $(1 \mathrm{~Hz})$, amplitude $(\mathrm{V})=0.005$ and quiet time $=2 \mathrm{~s}$. From Nyquist plot the values of charge transfer resistance $\left(R_{\mathrm{t}}\right)$ and the double layer capacitance $\left(C_{\mathrm{dl}}\right)$ were calculated.

\section{Results and Discussion}

\section{Analysis of results of weight loss study}

The inhibition efficiency (IE) of an aqueous extract of Ervatamia divaricata in controlling corrosion of carbon steel in ground water has been evaluated by weight loss method. The results are given Table 2. It is seen from Table 2 that when the carbon steel is immersed in ground water, the corrosion rate $(C R)$ is $17.87 \mathrm{mdd}$. When $0.5 \mathrm{ml}$ of $E D E$ are added, the $C R$ is reduced to $8.58 \mathrm{mdd}$ and the $I E$ is found to be $52 \%$. Upon addition of various concentration of $(1,1.5,2.0,2.5)$ of $E D E I E$ increases and corrosion rate decreases. This is due to the fact that the complex $\left(\mathrm{Fe}^{2+}\right.$-active principle in $\left.E D E\right)$ is formed on the metal surface.

It is seen from Table 2 that when zinc is added to the $E D E$, the $I E$ increases to a great extent. For example when $25 \mathrm{ppm}$ of $\mathrm{Zn}^{2+}$ is added to $1.5 \mathrm{ml}$ of extract, the $I E$ increases from $52 \%$ to $96 \%$. This suggests that a synergistic effect exists between the active principles present in $E D E$ and $\mathrm{Zn}^{2+}$. Thus, the inhibition efficiency $(I E)$ of $E D E$ extract $-\mathrm{Zn}^{2+}$ system in controlling corrosion of carbon steel in ground water has been evaluated by weight loss method. It is also observed that as the concentration of inhibitor increased, the inhibition efficiency also increased. This is due to the fact that as the concentration of increases the transport of inhibitor towards the metal surface also increases and hence $I E$ increases. 
Table 2. Inhibition efficiencies of the inhibitor system in controlling corrosion of carbon steel immersed in ground water, for a period of 3 days, obtained by weighty loss method. Inhibitor system: EDE extract- $\mathrm{Zn}^{2+}$ system.

\begin{tabular}{|c|c|c|c|c|c|c|c|c|c|c|c|c|}
\hline \multirow{3}{*}{ Extract (ml) } & \multicolumn{12}{|c|}{$\mathrm{Zn}^{2+} \mathbf{p p m}$} \\
\hline & \multicolumn{2}{|c|}{ 0 } & \multicolumn{2}{|c|}{5} & \multicolumn{2}{|c|}{10} & \multicolumn{2}{|c|}{15} & \multicolumn{2}{|c|}{20} & \multicolumn{2}{|c|}{25} \\
\hline & $C R$ & $I E$ & $C R$ & $I E$ & $C R$ & $I E$ & $C R$ & $I E$ & $C R$ & $I E$ & $C R$ & $I E$ \\
\hline 0 & 17.87 & - & 16.44 & 8 & 15.90 & 11 & 15.37 & 14 & 14.65 & 18 & 14.30 & 20 \\
\hline 0.5 & 8.58 & 52 & 8.23 & 54 & 7.51 & 58 & 3.58 & 80 & 3.76 & 79 & 3.04 & 83 \\
\hline 1.0 & 8.23 & 54 & 6.62 & 63 & 5.19 & 71 & 3.22 & 82 & 2.69 & 85 & 2.15 & 88 \\
\hline 1.5 & 7.87 & 56 & 6.44 & 64 & 5.01 & 72 & 3.04 & 83 & 1.61 & 91 & 0.72 & 96 \\
\hline 2.0 & 6.80 & 62 & 6.08 & 66 & 4.83 & 73 & 2.69 & 85 & 0.72 & 96 & 0.54 & 97 \\
\hline 2.5 & 4.83 & 71 & 5.19 & 73 & 3.76 & 79 & 2.14 & 88 & 0.54 & 97 & 0.36 & 98 \\
\hline
\end{tabular}

\section{Synergism parameters}

Synergism parameters indicate the synergistic effect existing between two inhibitor systems. Synergistic effect means that, a mixture of inhibitors shows better inhibition efficiency than the individual members. In the present study a synergistic effect exists between $E D E$ extract and $\mathrm{Zn}^{2+}$. Synergistic effects have been calculated considering the blocking effect.

The synergism parameter $\left(S_{\mathrm{I}}\right)$ have been calculated from the inhibition efficiencies and the surface coverage, giving importance to blocking effect. The calculation has been explained clearly in experimental section. If the value of $S_{\mathrm{I}}$ is greater than or equal to 1 , it is an indication of synergistic effect (Table 3 ).

Table 3. Synergism parameters.

\begin{tabular}{|c|c|c|c|c|c|c|c|c|c|c|c|}
\hline \multirow[t]{3}{*}{ Extract $(\mathrm{ml})$} & \multicolumn{11}{|c|}{$\mathbf{Z n}^{2+} \mathbf{p p m}$} \\
\hline & \multirow{2}{*}{$\begin{array}{l}\mathbf{0} \\
\boldsymbol{\theta}\end{array}$} & \multicolumn{2}{|c|}{5} & \multicolumn{2}{|c|}{10} & \multicolumn{2}{|c|}{15} & \multicolumn{2}{|c|}{20} & \multicolumn{2}{|c|}{25} \\
\hline & & $\theta$ & $S_{\text {I }}$ & $\boldsymbol{\theta}$ & $S_{\text {I }}$ & $\theta$ & $S_{\text {I }}$ & $\theta$ & $S_{\text {I }}$ & $\theta$ & $S_{\text {I }}$ \\
\hline 0 & - & 0.08 & - & 0.11 & - & 0.14 & - & 0.18 & - & 0.20 & - \\
\hline 0.5 & 0.52 & 0.54 & 0.96 & 0.58 & 1.01 & 0.80 & 2.06 & 0.79 & 1.87 & 0.83 & 2.26 \\
\hline 1.0 & 0.54 & 0.63 & 1.14 & 0.71 & 1.41 & 0.82 & 2.20 & 0.85 & 2.51 & 0.88 & 3.07 \\
\hline 1.5 & 0.56 & 0.64 & 1.12 & 0.72 & 1.40 & 0.83 & 2.22 & 0.91 & 4.01 & 0.96 & 8.80 \\
\hline 2.0 & 0.62 & 0.66 & 1.03 & 0.73 & 1.24 & 0.85 & 2.18 & 0.96 & 7.79 & 0.97 & 10.13 \\
\hline 2.5 & 0.71 & 0.73 & 0.99 & 0.79 & 1.23 & 0.88 & 2.08 & 0.97 & 7.93 & 0.98 & 11.60 \\
\hline
\end{tabular}




\section{Adsorption isotherm}

Corrosion inhibition is due to adsorption of inhibitor molecules on the metal surface and blocking effect. In the present study, when a plot is made by plotting $C v s$. $C / \theta$ (Table 4), a straight line is obtained, with a very high $R^{2}$ value (0.999) (Figure 1). This indicates that, Langmuir adsorption isotherm is obeyed, for the system consisting of $E D E$ extract and $25 \mathrm{ppm}$ of $\mathrm{Zn}^{2+}$.

Table 4. Langmuir adsorption isotherm parameters derived from weight loss methods.

\begin{tabular}{ccc}
\hline $\boldsymbol{C} \mathbf{m l}$ & $\boldsymbol{\theta}$ & $\boldsymbol{C} / \boldsymbol{\theta}$ \\
\hline 0.5 & 0.83 & 0.60 \\
1.0 & 0.88 & 1.14 \\
1.5 & 0.96 & 1.56 \\
2.0 & 0.97 & 2.06 \\
2.5 & 0.98 & 2.55 \\
\hline
\end{tabular}

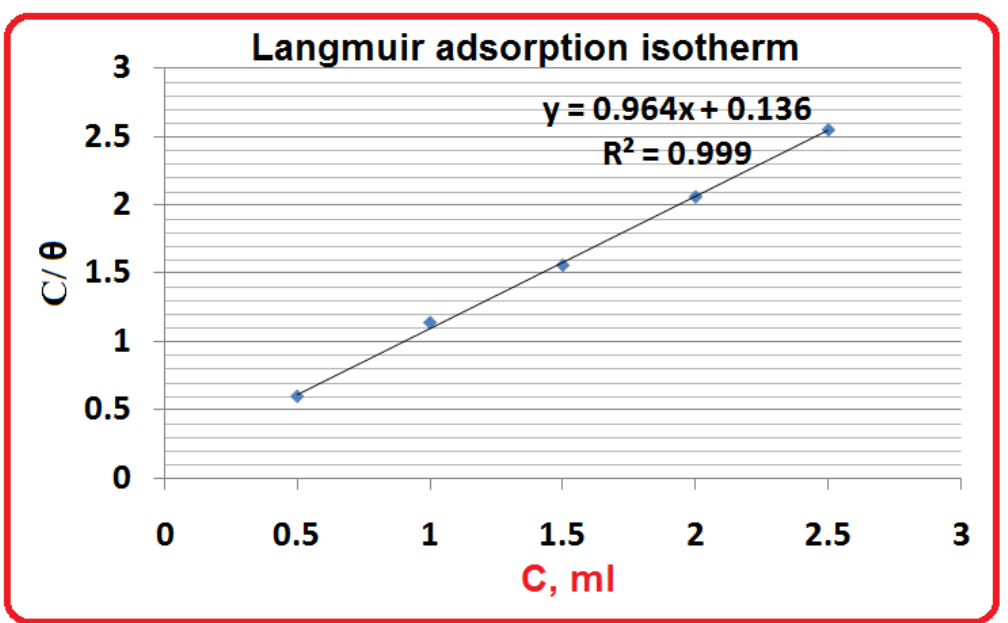

Figure 1. Langmuir adsorption isotherm.

\section{Electrochemical studies}

Electrochemical studies such as polarization study and AC impedance spectra have been extensively used in the corrosion inhibition studies. In the presence of inhibitors, linear polarization resistance $(\mathrm{LPR})$ increases, corrosion current decreases $\left(I_{\text {corr }}\right)$, charge transfer resistance $\left(R_{\mathrm{t}}\right)$ increases, double layer capacitance $\left(C_{\mathrm{dl}}\right)$ decreases, impedance increases and phase angle increases (Figure 2). 


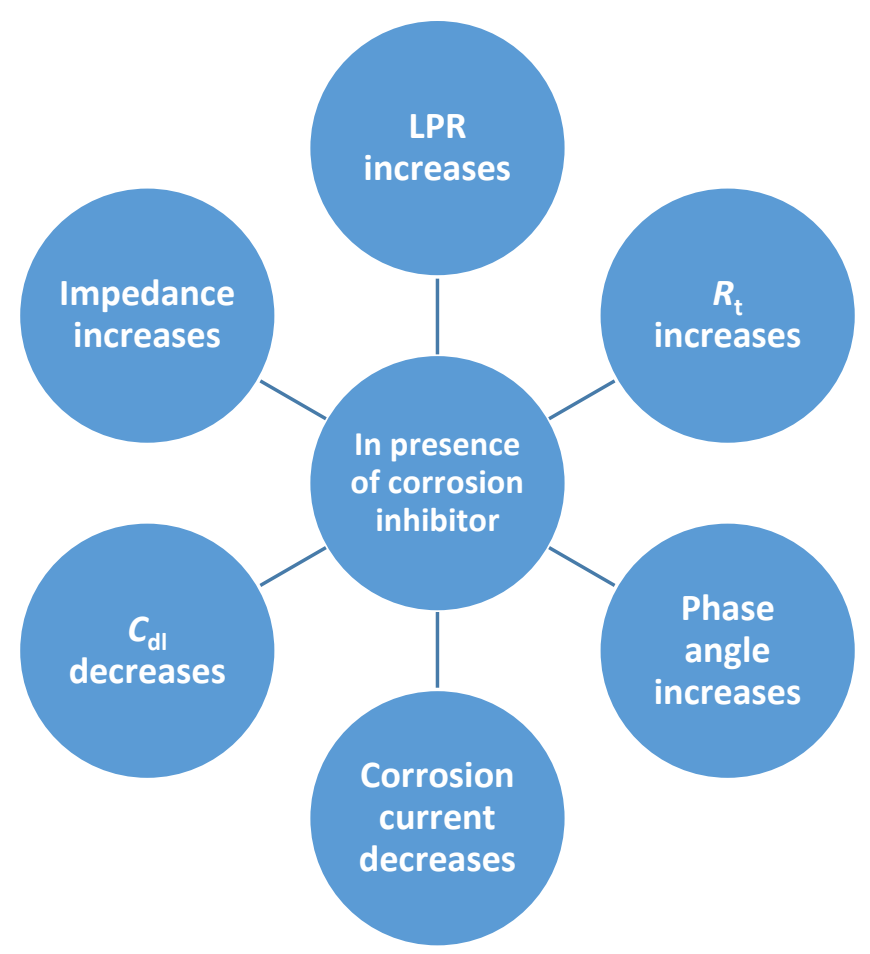

Figure 2. Correlation among corrosion inhibitors and various corrosion parameters.

\section{Polarization study}

The polarization parameters such as, linear polarization resistance (LPR), corrosion current $\left(I_{\text {corr }}\right)$, corrosion potential $\left(E_{\text {corr }}\right)$, and Tafel slopes $\left(b_{\mathrm{c}}=\right.$ cathodic, $b_{\mathrm{a}}=$ anodic $)$ are given in Table 5. The polarization curves are shown in Figure 3.

It is seen from Table 5 that when the inhibitor system consisting of EDE extract and $25 \mathrm{ppm}$ of $\mathrm{Zn}^{2+}$ is added to ground water, the corrosion resistance of carbon steel increases. This is revealed by the fact that when the inhibitor system is introduced into ground water, the LPR values increases and $I_{\text {corr }}$ value decreases (Figure 4, Table 5). In presence of inhibitor, the corrosion potential is shifted to the anodic side. This indicates that the anodic reaction is controlled predominantly [14-18].

Table 5. Corrosion parameters of carbon steel immersed in ground water in the absence and presence of $E D E$ extract and $\mathrm{Zn}^{2+}\left(\mathrm{ZnSO}_{4} \cdot 7 \mathrm{H}_{2} \mathrm{O}\right)$ obtained by Polarization study.

\begin{tabular}{|c|c|c|c|c|c|}
\hline System & $\begin{array}{c}E_{\text {corr }} \\
\mathrm{mV} \text { SCE }\end{array}$ & $\begin{array}{c}b_{c} \\
\text { V/decade }\end{array}$ & $\begin{array}{c}b_{\text {a }} \\
\text { V/decade }\end{array}$ & 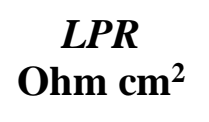 & $\begin{array}{c}I_{\text {corr }} \\
\mathbf{A} / \mathbf{c m}^{2}\end{array}$ \\
\hline Ground water (GW) & -993 & 7.142 & 3.224 & 924 & $4.538 \cdot 10^{-5}$ \\
\hline $\begin{array}{c}\mathrm{GW}+2.5 \mathrm{ml} E D E+ \\
\mid+25 \mathrm{ppm} \mathrm{Zn}^{2+}\end{array}$ & -685 & 4.836 & 6.956 & 1380 & $2.671 \cdot 10^{-5}$ \\
\hline
\end{tabular}




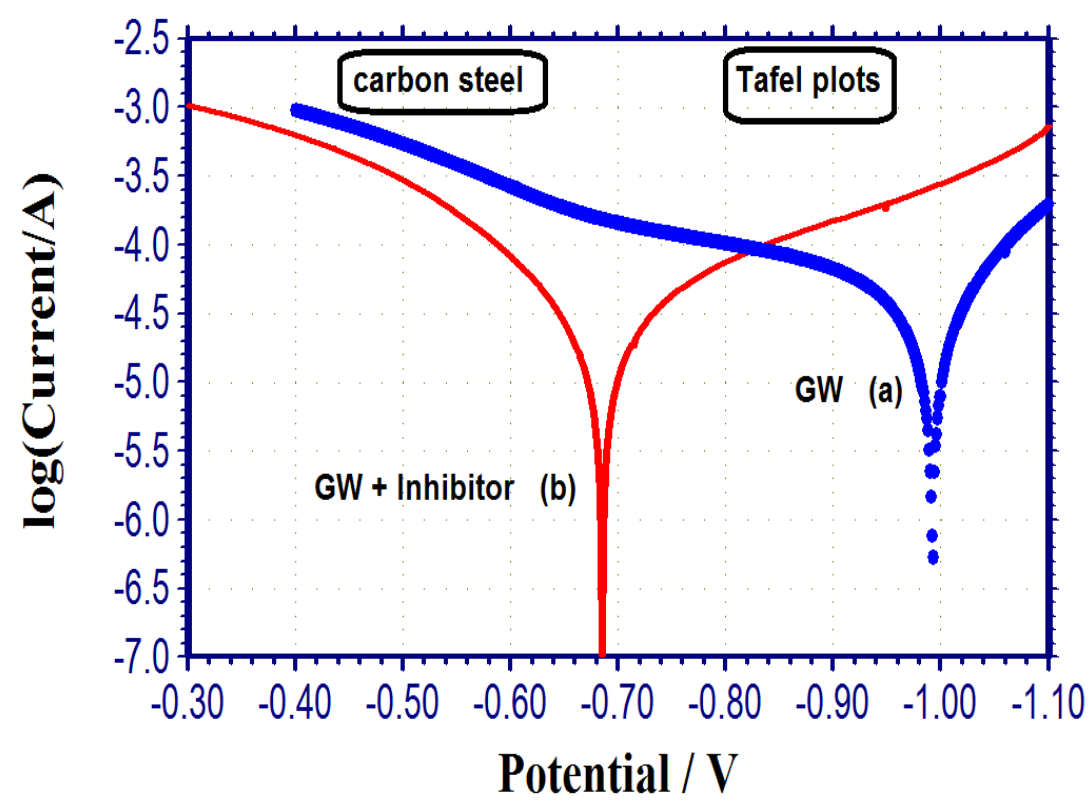

Figure 3. Polarisation curves of carbon steel immersed in various test solutions $(a)$ Ground water, (b) Ground water+inhibitor.

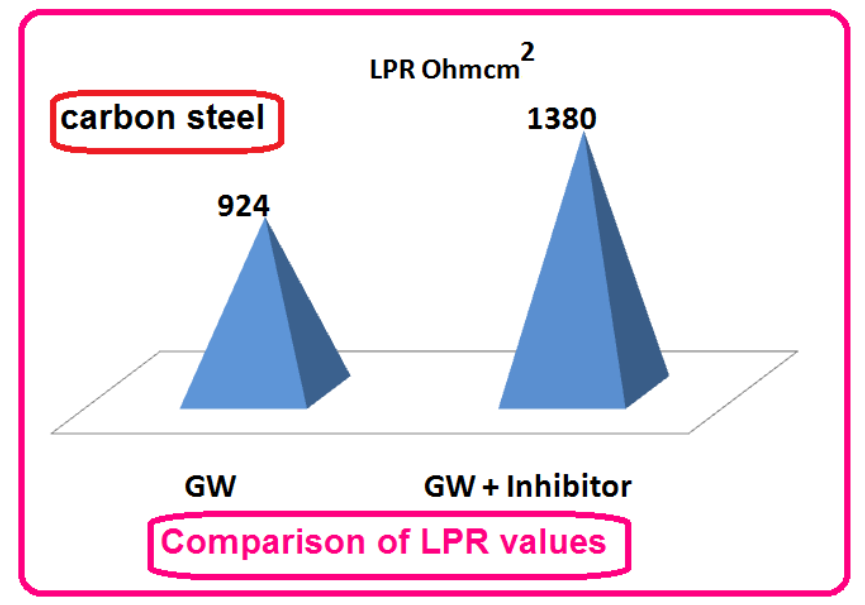

Figure 4. Comparison of $L P R$ values of various systems.

Implication: Polarization study leads to the conclusion that, when the inhibitor system consisting of $E D E$ extract and $25 \mathrm{ppm}$ of $\mathrm{Zn}^{2+}$ is added to ground water, the corrosion resistance of carbon steel increases. This is revealed by the fact that when the inhibitor system is introduced into ground water, the LPR values increases and $I_{\text {corr }}$ value decreases. This is due to the formation of a protective film (blocking film) formed on the metal surface. The protective film probably consists of $\mathrm{Fe}^{2+}$-active principle complex formed on the anodic sites of the metal surface and $\mathrm{Zn}(\mathrm{OH})_{2}$ on the cathodic sites of the metal surface which are responsible for blocking effect. 


\section{AC impedance spectra}

The AC impedance spectra (Nyquist plots, Bode plots) of carbon steel immersed in various test solutions are shown in Figures 5-7. The corrosion parameters, namely, charge transfer resistance $\left(R_{\mathrm{t}}\right)$, double layer capacitance $\left(C_{\mathrm{dl}}\right)$, impedance and phase angle are given in Table 6. It is observed from Table 6 , that when the inhibitor system is added to ground water, the corrosion resistance of carbon steel increases. This is revealed by the fact that there is increase in $R_{\mathrm{t}}$ value (Figure 8), impedance value, increase in phase angle, and decrease in $C_{\mathrm{dl}}$ value [19-26].

Table 6. Corrosion parameters of carbon steel immersed in ground water in the absence and presence of $E D E$ extract and $\mathrm{Zn}^{2+}\left(\mathrm{ZnSO}_{4} \cdot 7 \mathrm{H}_{2} \mathrm{O}\right)$ obtained by $\mathrm{AC}$ impedance spectra.

\begin{tabular}{ccccc}
\hline System & $\begin{array}{c}\boldsymbol{R}_{\mathbf{t}} \\
\mathbf{O h m} \mathbf{~ c m}^{\mathbf{2}}\end{array}$ & $\begin{array}{c}\boldsymbol{C}_{\mathrm{dl}} \\
\mathbf{F} / \mathbf{c m}^{\mathbf{2}}\end{array}$ & $\begin{array}{c}\text { Impedance } \\
\mathbf{L o g}(\boldsymbol{Z} / \mathbf{O h m})\end{array}$ & $\begin{array}{c}\text { Phase angle } \\
\text { (degrees) }\end{array}$ \\
\hline Ground water $(\mathrm{GW})$ & 57.84 & $8.82 \cdot 10^{-8}$ & 1.925 & 29.18 \\
\hline $\mathrm{GW}+2.5 \mathrm{ml} E D E+25 \mathrm{ppm} \mathrm{Zn}^{2+}$ & 150.87 & $3.38 \cdot 10^{-8}$ & 2.3 & 32.41 \\
\hline
\end{tabular}

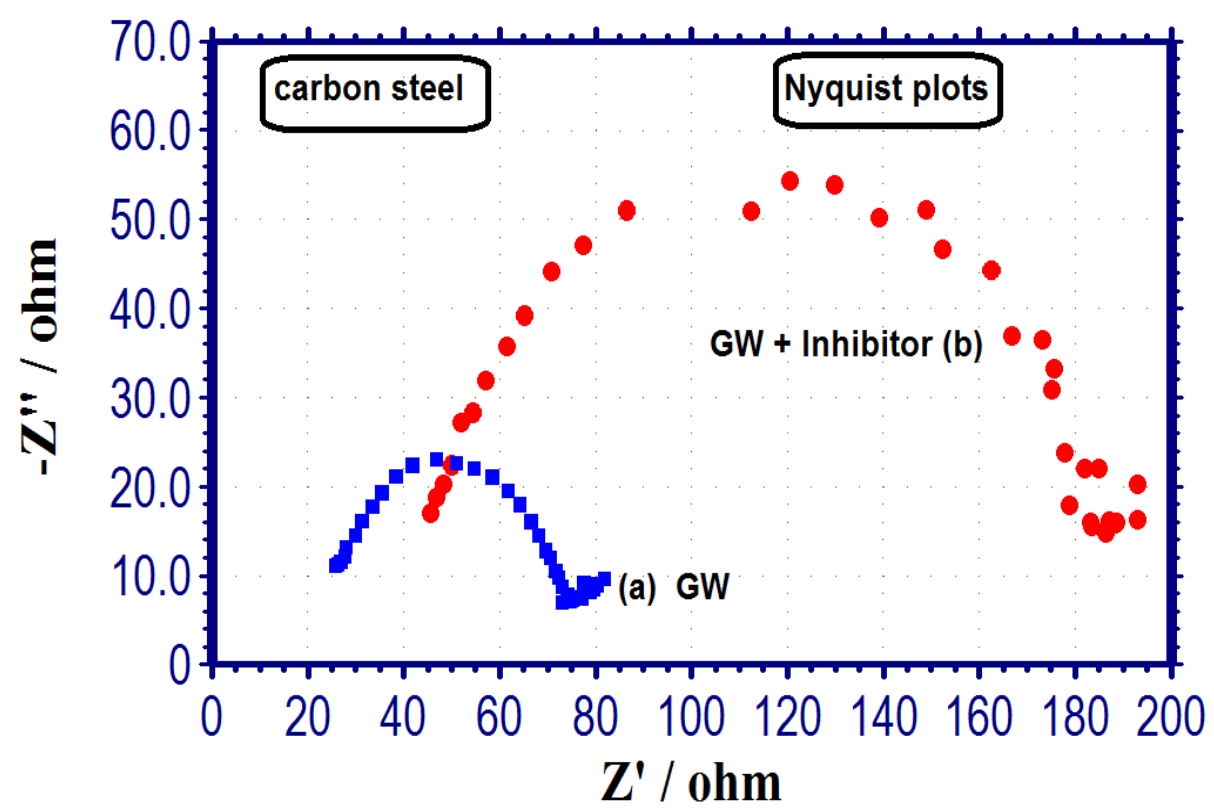

Figure 5. Nyquist plots of carbon steel immersed in various test solutions. (a) GW; (b) $\mathrm{GW}+$ inhibitor. 


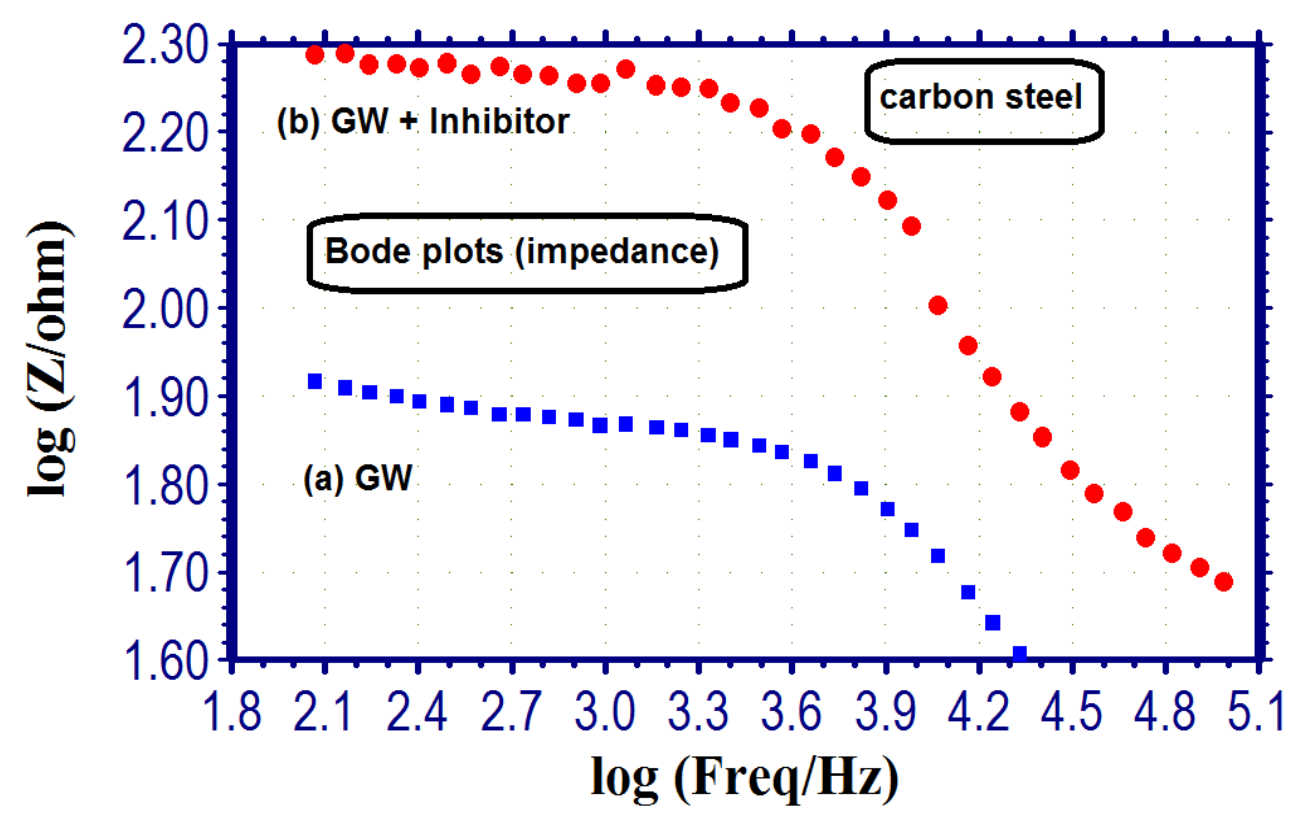

Figure 6. Bode plots (impedance) of carbon steel immersed in various test solutions. (a) GW; (b) GW+inhibitor.

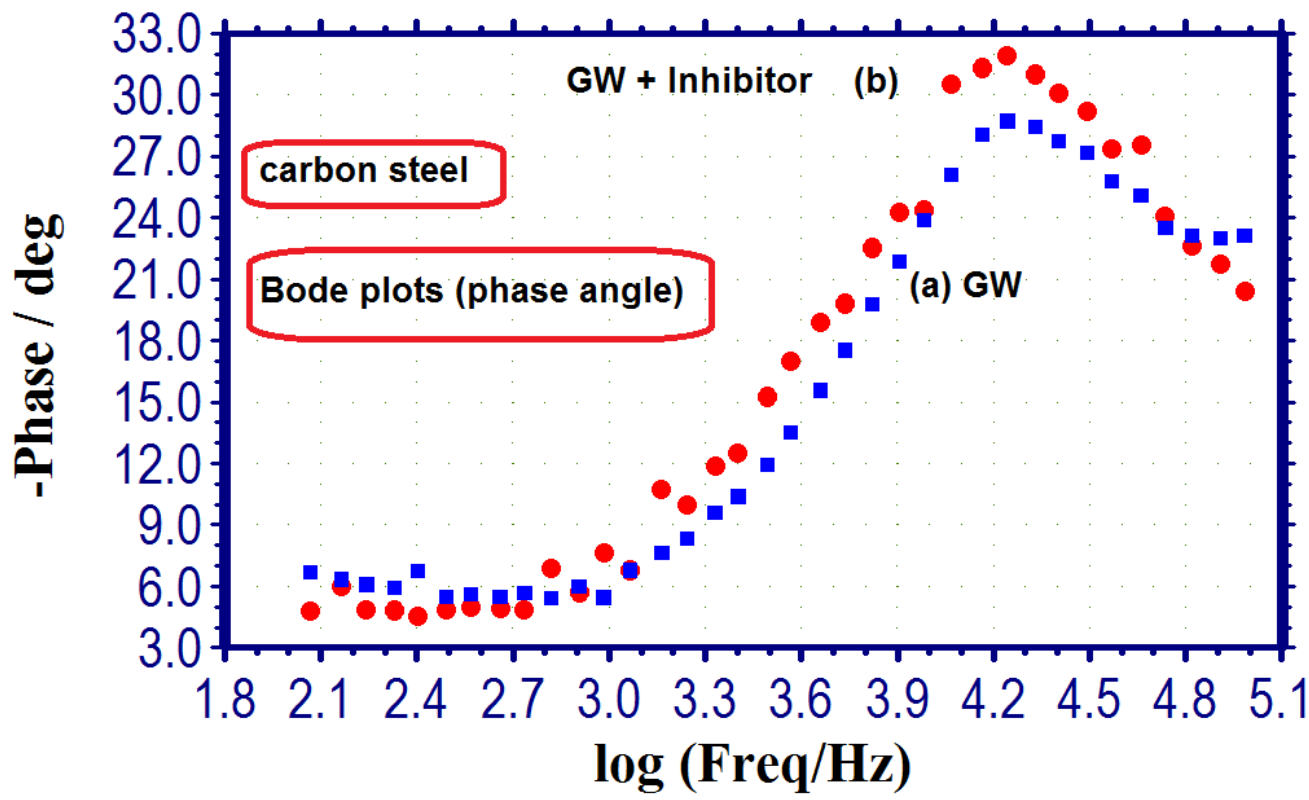

Figure 7. Bode plots (phase angle) of carbon steel immersed in various test solutions. (a) GW; (b) GW+inhibitor.

The equivalent circuit diagram is shown in Figure 9. This explains how solution resistance, charge transfer resistance, double layer capacitance and working electrode are connected. Solution resistance is measured in the high frequency region. "Charge transfer resistance + Solution resistance" is measured in the low frequency region. 


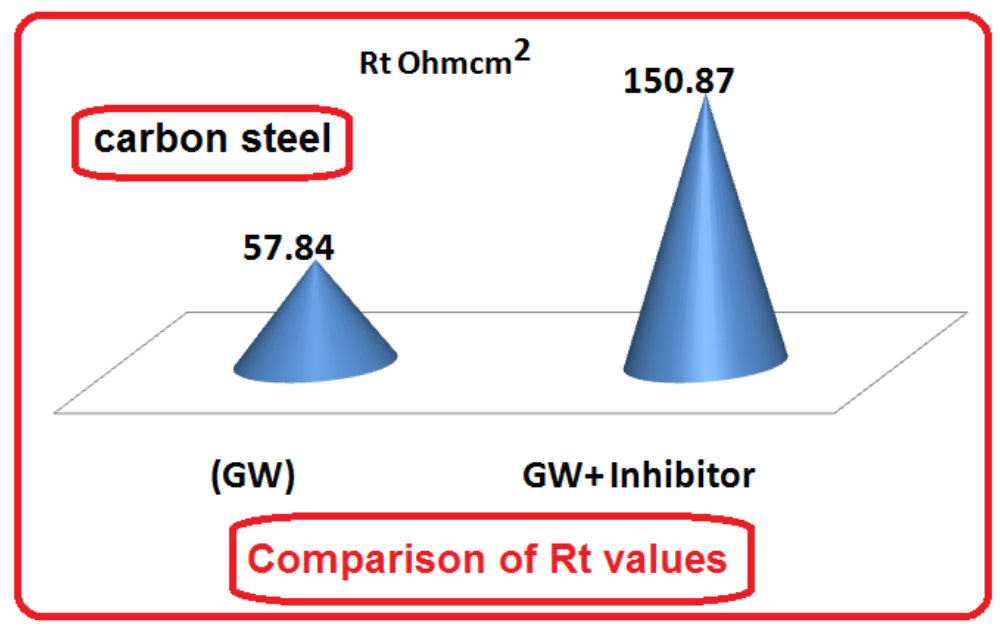

Figure 8. Comparison of $R_{\mathrm{t}}$ values.

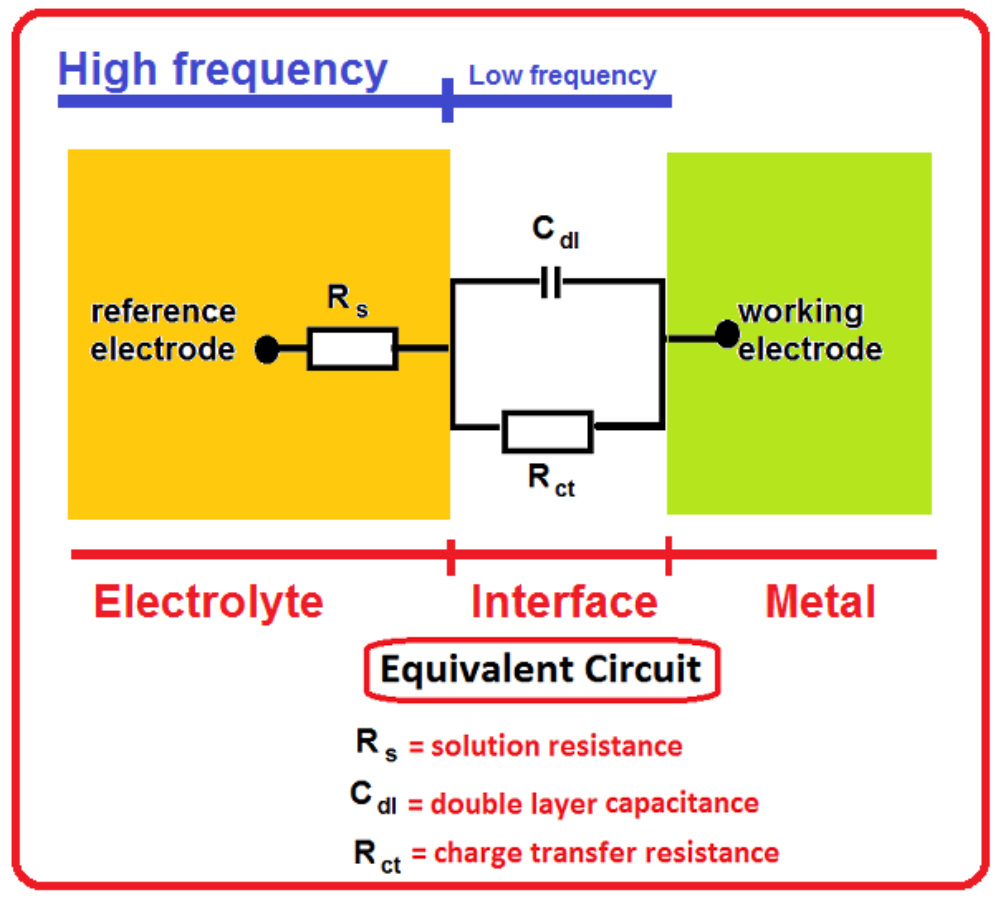

Figure 9. Equivalent circuit diagram.

Implication: AC impedance spectral study leads to the conclusion that, when the inhibitor system consisting of $E D E$ extract and $25 \mathrm{ppm}$ of $\mathrm{Zn}^{2+}$ is added to ground water, the corrosion resistance of carbon steel increases. This is revealed by the fact that, when the inhibitor system is introduced into ground water, there is increase in $R_{\mathrm{t}}$ value, impedance value, increase in phase angle, and decrease in $C_{\mathrm{dl}}$ value. This is due to the formation of a protective film (blocking film) formed on the metal surface. The protective film probably consists of $\mathrm{Fe}^{2+}$-active principle complex formed on the anodic sites of the metal surface and also $\mathrm{Zn}(\mathrm{OH})_{2}$ on the cathodic sites of the metal surface. 


\section{Analysis of Vickers hardness}

Hardness of a material can be measured by Vickers hardness test. The unit is called the Vickers Pyramid Number $(H V)$. The ability of a metal to withstand the plastic deformation from a standard source is measured.

The hardness was measured for polished mild steel surface (system A), polished mild steel surface engrossed in corrosive medium, that is ground water (GW) (system B) and polished mild steel surface kept in corrosive medium $(\mathrm{GW})$ containing the inhibitor system, that is plant extract containing $\mathrm{Zn}^{2+}$ (system $\mathrm{C}$ ). The values are given in Table 7 .

Table 7. Vickers Hardness $(H V)$ of various surfaces measured along L1 and L2.

\begin{tabular}{cccc}
\hline System (load) $\boldsymbol{S}$. No. & L1 & L2 & $\boldsymbol{H V}$ \\
\hline Polished metal (25 g) 1 & 22.87 & 35.32 & 79.8 \\
Polished metal (25 g) 2 & 22.29 & 25.13 & 82.4 \\
Corroded metal (25 g) Ground water 1 & 36.29 & 39.03 & 32.2 \\
Corroded metal (25 g) Ground water 2 & 36.44 & 38.12 & 33.3 \\
Inhibited metal (25 g) Extract $\mathrm{Zn}^{2+}$ 1 & 26.37 & 28.40 & 61.8 \\
Inhibited metal (25 g) GW+Extract+Zn ${ }^{2+} 2$ & 26.69 & 28.21 & 61.5 \\
\hline
\end{tabular}

It is observed that for system A the hardness is high. For system B the hardness is low, because the corroded surface contains iron oxide film which is porous and amorphous. Surface is hardly rough. Pits are noticed due to corrosion. For system C the surface is smooth. This is attributed to the deposition of shielding layer (blocking layer). The hardness is in between that of systems A and B. That is, lower than that of polished metal but higher than that of corroded surface. Thus the Vickers hardness is used in corrosion inhibition study (Figure 10).

Table 8. Vickers Hardness $(H V)$ of various surfaces (average values).

\begin{tabular}{cc}
\hline System (load) & $\boldsymbol{H V}$, average \\
\hline Polished metal $(25 \mathrm{~g})$ & 81.10 \\
Corroded metal $(25 \mathrm{~g})$ in Ground water & 32.75 \\
Inhibited metal $(25 \mathrm{~g})$ in GW+Extract $+\mathrm{Zn}^{2+}$ & 61.65 \\
\hline
\end{tabular}




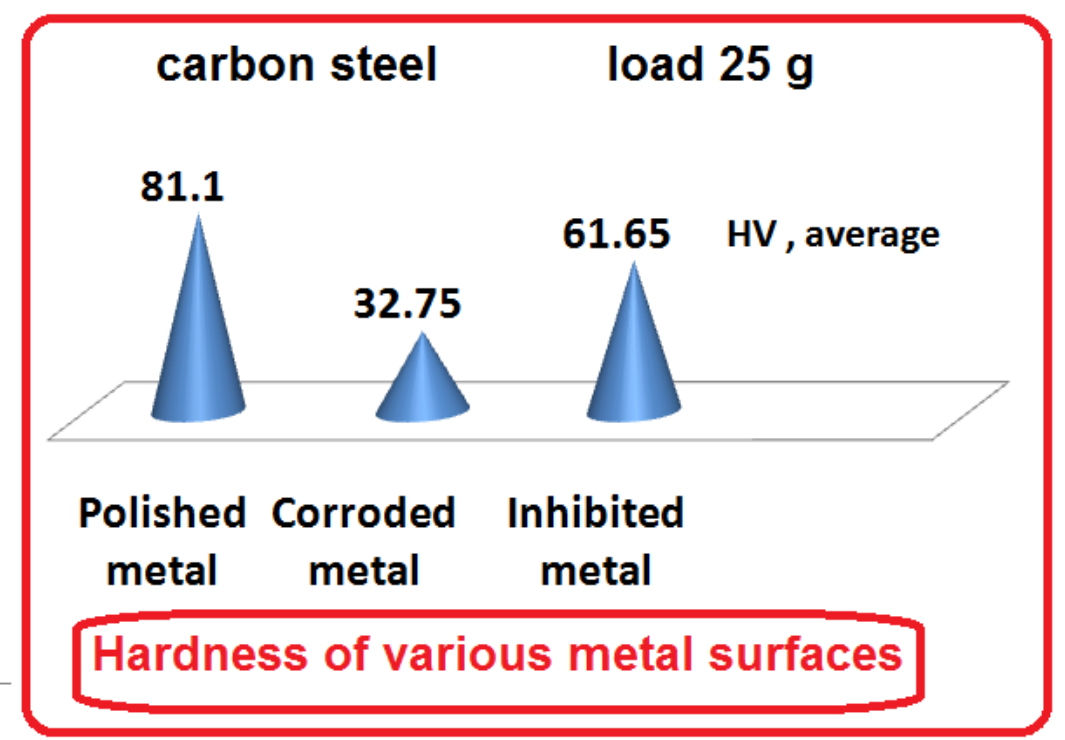

Figure 10. Comparison of hardness of various metal surfaces.

\section{Analysis of FTIR Spectra}

The structure of active principle of Ervatamia divaricata extract, namely, corynanthean is shown in Figure 11.

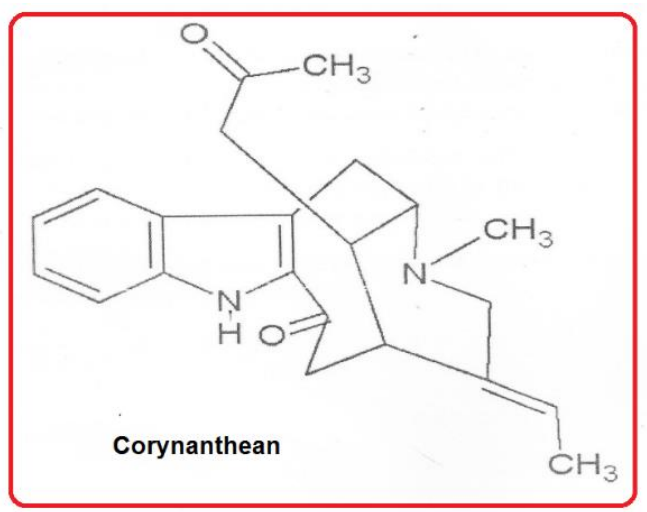

Figure 11. Structure of Corynanthean.

A few drops of an aqueous extract of Ervatamia divaricata were placed on a glass plate and evaporated to dryness. A solid mass was obtained. Its FTIR spectrum is shown in Figure 12. The $\mathrm{N}-\mathrm{H}$ stretching frequency appears at $3513.65 \mathrm{~cm}^{-1}$.

The peak at $1642.75 \mathrm{~cm}^{-1}$ corresponds to $\mathrm{C}=\mathrm{O}$ stretching frequency of ketone group. The peak at $1046.29 \mathrm{~cm}^{-1}$ corresponds to $\mathrm{C}=\mathrm{C}$ stretching frequency. Thus, the structure of Corynanthean is confirmed by FTIR spectrum.

The FTIR spectrum of the protective film formed on the surface of the metal after immersion in the ground water containing $\mathrm{Zn}^{2+}$ and $E D E$ is shown in Figure 13. It is found that $\mathrm{N}-\mathrm{H}$ stretching frequency has shifted from $3513.65 \mathrm{~cm}^{-1}$ to $3443.91 \mathrm{~cm}^{-1}$, while $\mathrm{C}=\mathrm{O}$ stretching frequency has shifted from $1642.75 \mathrm{~cm}^{-1}$ to $1616.24 \mathrm{~cm}^{-1}$. The $\mathrm{C}=\mathrm{C}$ stretching 
frequency has shifted from $1046.29 \mathrm{~cm}^{-1}$ to $1060.03 \mathrm{~cm}^{-1}$. The peak at $1396 \mathrm{~cm}^{-1}$ is due to zinc hydroxide formed on metal surface. The peak at $663.42 \mathrm{~cm}^{-1}$ is due to metal-oxygen bond. The peak at $3443.91 \mathrm{~cm}^{-1}$ is due to hydroxyl group. Thus, the formation of zinc hydroxide on the cathodic sites of the metal surface is confirmed.

The FTIR spectral study leads to the conclusion that the protective film consists of $\mathrm{Fe}^{2+}$ (Corynanthean) complex and $\mathrm{Zn}(\mathrm{OH})_{2}$.

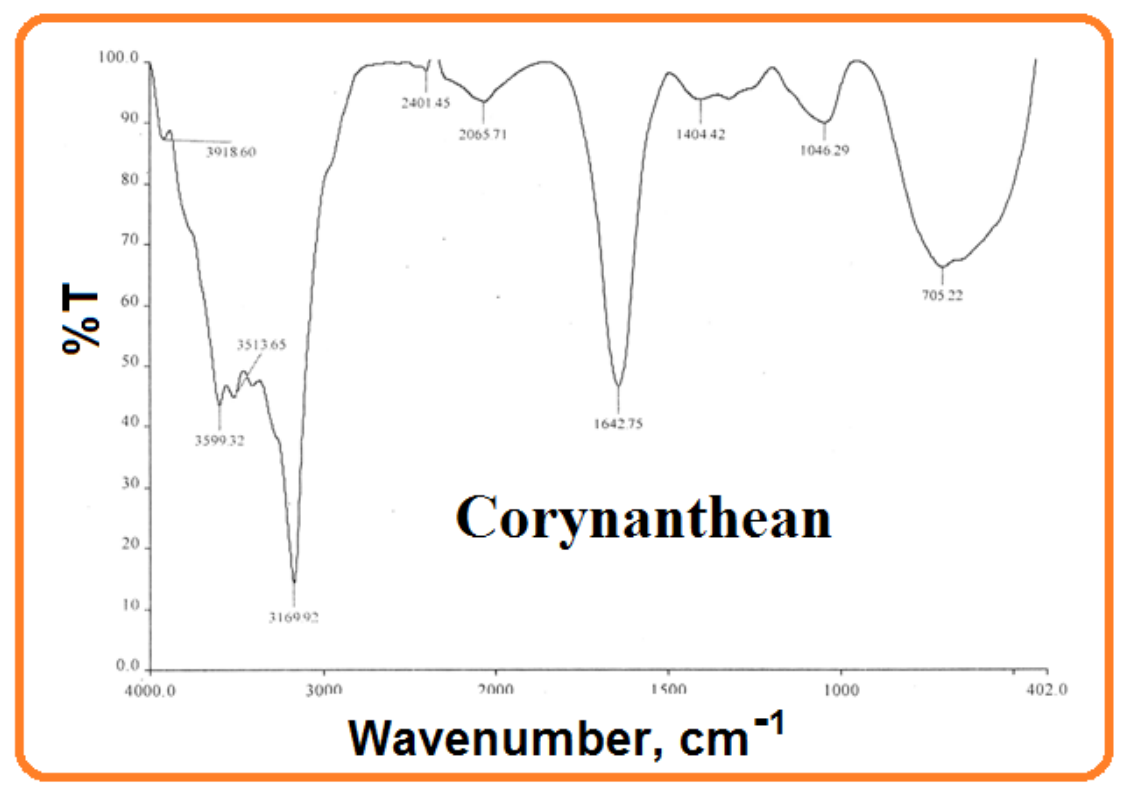

Figure 12. FTIR Spectrum of aqueous extract of $E D E$ evaporated to dryness.

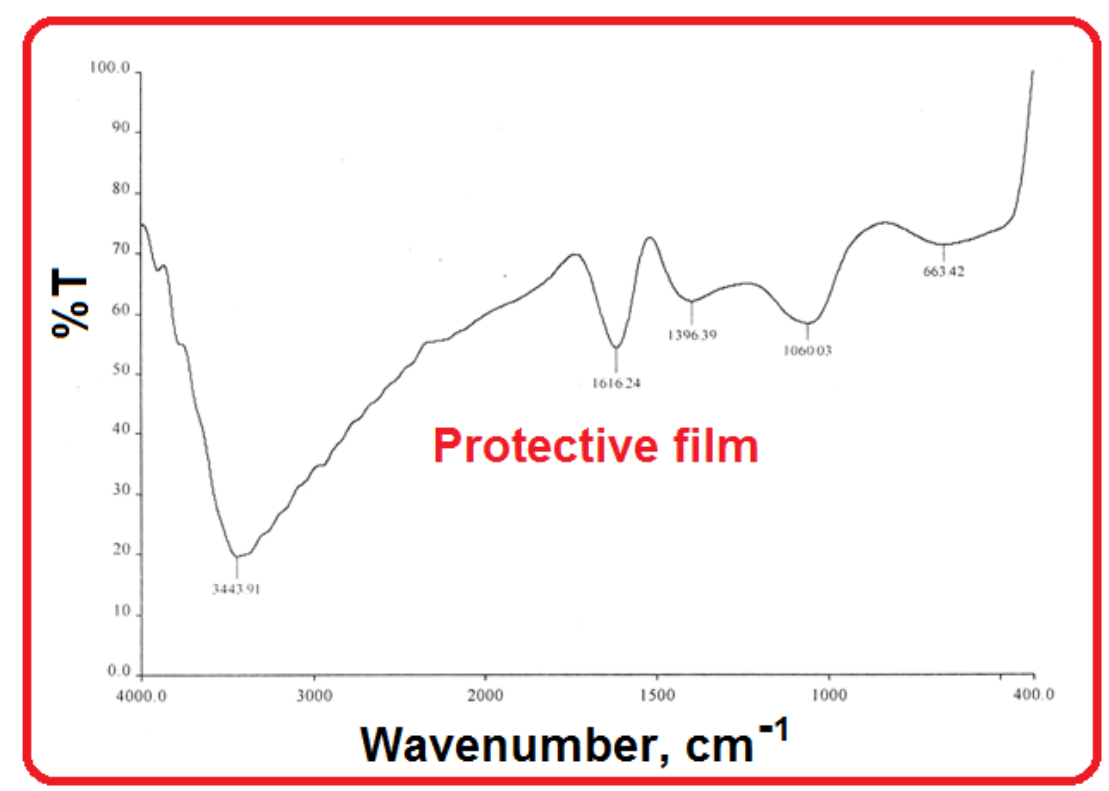

Figure 13. FTIR spectrum protective film formed on the surface metal after immersion in the ground water containing $\mathrm{Zn}^{2+}$ and $E D E$. 


\section{Conclusions}

The corrosion inhibition efficiency (IE) of Ervatamia divaricata extract $(E D E)$ and $\mathrm{Zn}^{2+}$ system in controlling corrosion of carbon steel in ground water has been evaluated by weight loss method. The study leads to the following conclusions.

- Weight loss study reveals that the formulation consisting of $2.5 \mathrm{ml}$ of $E D E$ and $25 \mathrm{ppm}$ $\mathrm{Zn}^{2+}$ has $98 \%$ inhibition efficiency in controlling corrosion of carbon steel immersed in ground water.

- Synergism parameters (calculated based on blocking effect [27]) suggest that a synergistic effect exists between $E D E$ and $\mathrm{Zn}^{2+}$.

- FTIR study reveals that a protective film is formed on the metal surface consisting of $\mathrm{Fe}^{2+}$ - Corynanthean complex and $\mathrm{Zn}(\mathrm{OH})_{2}$.

- The anodic reaction is controlled by the $\mathrm{Fe}^{2+}-$ Corynanthean complex formed on the anodic sites of the metal surface and the cathodic reaction is controlled by $\mathrm{Zn}(\mathrm{OH})_{2}$ formed on the cathodic sites of the metal surface.

- The hardness of the metal surface containing the protective film is in between that of polished metal and that of the corroded metal in ground water.

- Electrochemical studies such as polarisation study and AC impedance spectra have been employed to investigate the mechanistic aspects of the corrosion inhibition.

- These studies confirm the formation of protective film formed on the metal surface.

- Adsorption isotherm study reveals that the adsorption of inhibitors on the metal surface obey Langmuir adsorption isotherm.

\section{Acknowledgement}

The authors are thankful to their respective managements for their help and encouragement. Special thanks to Rev. Dr. Antony Pushpa Ranjitham (Superior General), Rev. Sr. Thanaseeli Sengole (Asst. General), Rev. Sr. M. Margaret Inbaseeli (College Secretary), Rev. Dr. Pramila (Principal), Rev. Sr. Gnana Soundari (Provincial) and Mrs J. Antony Justina Mary (Vice Principal) for their Prayer and Blessings.

\section{References}

1. N. Raghavendra and J.I. Bhat, J. Bio Tribo Corros., 2016, 2, 21. doi: 10.1007/s40735016-0051-2

2. D.I. Njoku, I. Ukaga, O.B. Ikenna, E.E. Oguzie, K.L. Oguzie and N. Ibisi, J. Molec. Liquids, 2016, 219, 417-424. doi: 10.1016/j.molliq.2016.03.049

3. R. Venegas, F. Figueredo, G. Carvallo, A. Molinari and R. Vera, Int. J. Electrochem. Sci., 2016, 11, no. 5, 3651-3663. doi: 10.20964/110449

4. A. Salhi, A. Bouyanzer, I.El Mounsi, I. Hamdani, H. Bendaha, R. Rmili, H. Akichouh, M. Allali, A. Zarrouk, B. Hammouti and J. Costa, Der Pharma. Lettre, 2016, 8, no. 2, 79-89. 
5. M.A. Al-Khaldi, Asian J. Chem., 2016, 28, no. 11, 2532-2538.

6. D.P. Emerenciano, A.C.C Andrade, M.L. De'Medeiros, M.F.V. De'Moura and M.A.M. MaCiel, Corrosion Inhibitors: Principles, Mechanisms and Applications, 2016, 79-104.

7. N.T. Yahia, O.M. Ridha and L.S. Eddine, Int. J. Current Pharma. Review and Res. Arch., 2016, 7, no. 4, 193-197.

8. H.H. Abdel Rahman, S.M. Seleim, A.M. Hafez and A.A. Helmy, Green Chem. Lett. Rev., 2015, 8, no. 3, 88-94.

9. B.V.R. De'Assis, F.O. Meira, V.G.S.S. Pina, (...), E. D'Elia, F.C. De'Souza, Revista Virtual de Quimica, 2015, 7, no. 5, 1830-1840.

10. I.B. De Barros, H.Z.L Moscoso, D.L. Custódio, V.F. Veiga, I.N. Bastos, Revista Virtual de Quimica, 2015, 7, no. 5, 1743-1755.

11. Y.C. Kuo, C.M. Sun, W.J. Tsai, J.C. Ou, W.P. Chen and C.Y. Lin, Life Sci., 1999, 64, 2089-2099. doi: 10.1016/S0024-3205(99)00158-7

12. M. Mandal and S. A. Mukherji, J. Environ. Biol., 2001, 22, 301-305.

13. Kulshreshtha and Jyoti Saxena, Int. J. Research \& Review, 2019, 6, no. 8, 517-524.

14. R. Nagalakshmi, L. Nagarajan, R.J. Rathish, S.S. Prabha, N. Vijaya, J. Jeyasundari and S. Rajendran, Int. J. Nano. Corr. Sci. Engg., 2014, 1, 39-49.

15. J.A. Thangakani, S. Rajendran, J. Sathiabama, R.M. Joany, R.J. Rathis and S.S. Prabha, Int. J. Nano. Corr. Sci. Engg., 2014, 1, 50-62.

16. A. Nithya, P. Shanthy, N. Vijaya, R.J. Rathish, S.S. Prabha, R.M. Joany and S. Rajendran, Int. J. Nano Corr. Sci. Engg., 2015, 2, 1-11.

17. A.C.C. Mary, S. Rajendran, H. Al-Hashem, R.J. Rathish, T. Umasankareswari and J. Jeyasundari, Int. J. Nano Corr. Sci. Engg., 2015, 2, 42-50.

18. A. Anandan, S. Rajendran, J. Sathiyabama and D. Sathiyaraj, Int. J. Corros. Scale Inhib., 2017, 6, no. 2, 132-141. doi: 10.17675/2305-6894-2017-6-2-3

19. C.O. Akalezi, C.E. Ogukwe, E.A. Ejele and E.E. Oguzie, Int. J. Corros. Scale Inhib., 2016, 5, no. 2, 132-146. doi: 10.17675/2305-6894-2016-5-2-3

20. T.A. Onat, D. Yiğit, H. Nazır, M. Güllü and G. Dönmez, Int. J. Corros. Scale Inhib., 2016, 5, no. 3, 273-281. doi: $10.17675 / 2305-6894-2016-5-3-7$

21. A.S. Fouda, M.A. El-Morsy, A.A. El-Barbary and L.E. Lamloum, Int. J. Corros. Scale Inhib., 2016, 5, no. 2, 112-131. doi: 10.17675/2305-6894-2016-5-2-2

22. V.I. Vigdorovich, L.E. Tsygankova, E.D. Tanygina, A.Yu. Tanygin and N.V. Shel, Int. J. Corros. Scale Inhib., 2016, 5, no. 1, 59-65. doi: 10.17675/2305-6894-2016-5-1-5

23. P.N. Devi, J. Sathiyabama and S. Rajendran, Int. J. Corros. Scale Inhib., 2017, 6, no. 1, 18-31. doi: 10.17675/2305-6894-2017-6-1-2

24. P. Mahalakshmi, S. Rajendran, G. Nandhini, S.C. Joycee, N. Vijaya, T. Umasankareswari and N. Renuga Devi, Int. J. Corros. Scale Inhib., 2020, 9, no. 2, 706-725. doi: $\underline{10.17675 / 2305-6894-2020-9-2-20}$ 
25. N. Karthiga, J.M. Praveena, A. Deepika, A.J.A. Fathim, R. Bhuvaneshwari, G.D. Christina, V.D. Mary, N. Renuga Devi, T. Umasankareswari and S. Rajendran, Int. J. Corros. Scale Inhib., 2020, 9, no. 2, 595-606. doi: 10.17675/2305-6894-2020-9-2-14 26. A. Grace Baby, S. Rajendran, V. Johnsirani, A. Hashem, N. Karthiga and P. Nivetha, Int. J. Corros. Scale Inhib., 2020, 9, no. 3, 979-999. doi: 10.17675/2305-6894-2020-93-12

27. Yu.I. Kuznetsov, N.N. Andreev and S.S. Vesely, Int. J. Corros. Scale Inhib., 2015, 4, no. $2,108-109$. 